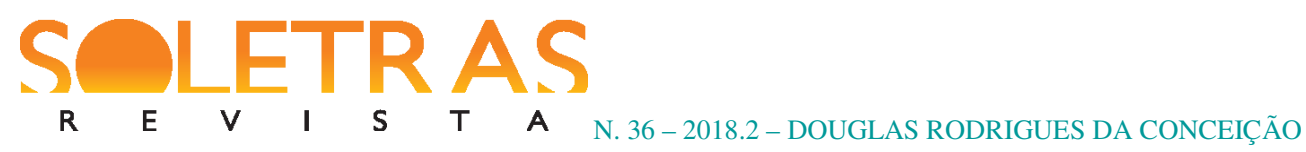

\title{
A religião como matéria prima da poesia
}

\author{
Douglas Rodrigues da Conceição ${ }^{1}$
}

\begin{abstract}
Resumo: O presente artigo, partindo da perspectiva que põe em evidência as relações estabelecidas entre religião e literatura no campo das Ciências da Religião, visita a poesia de Luís Augusto Cassas, poeta contemporâneo, mas antes sobrevoa muito brevemente a poesia de Gregório de Matos. Mais do que propor somente uma crítica à religião pela poesia de Cassas, o texto em questão pretende abrir portas para que se pense, sobretudo, a religião enquanto matéria prima das expressões literárias.
\end{abstract}

Palavras-chave: Religião. Poesia. Crítica. Luís Augusto Cassas.

\section{Um breve horizonte}

A efetiva presença da literatura no campo das Ciências da Religião - de onde parto - é relativamente recente, caso não queiramos considerar, aqui, os estudos de literatura bíblica e outras escrituras feitos a partir de uma matriz propriamente exegética histórico-crítica. $\mathrm{O}$ acolhimento da literatura em seus domínios fez com que as Ciências da Religião ampliassem naturalmente o seu espectro epistemológico. Como lidar, então, com um objeto que naturalmente pertence a outros domínios investigativos e não às Ciências da Religião? É, portanto, de uma breve problematização da presença da literatura no campo dos estudos de religião que eu desejaria partir e mais adiante tomar dois exemplos que recolocam em cena duas perspectivas de cotejamento da literatura nesta tradição de estudos e pesquisa. ${ }^{2}$

A expressiva presença de teólogos nas escolas de Ciências da Religião, ao que eu atribuo a guinada dos estudos de religião em direção à literatura, no Brasil, pelo menos, fez com que os domínios de investigação da teologia fossem pensados não só como chaves indispensáveis de exploração científica de certos aspectos da religião, o que deslocaria

\footnotetext{
${ }^{1}$ Doutor em Ciências da Religião, UMESP. Estágio Pós-Doutoral, Université Paris Nanterre. Professor Adjunto IV da Universidade do Estado do Pará. Atua como docente permanente do Programa de Pós-Graduação em Ciências da Religião (PPGCR) da Universidade do Estado do Pará (UEPA), Belém, PA, Brasil. E-mail: abismos@gmail.com. O presente trabalho foi realizado com apoio da Coordenação de Aperfeiçoamento de Pessoal de Nível Superior - Brasil (CAPES) - Código de Financiamento 001.

${ }^{2}$ Embora amplamente conhecidos na área de Ciências da Religião, apresento aqui os trabalhos que contribuíram de modo seminal para a criação do referido campo de investigação. São eles: MANZATTO, Antonio. Teologia e literatura: reflexão teológica a partir da antropologia contida nos romances de Jorge Amado. São Paulo: Loyola, 1994; MAGALHÃES, Antonio. Deus no espelho das palavras: teologia e literatura em diálogo. São Paulo: Paulinas, 2001; TENÓRIO, Waldecy. A bailadora andaluza: a explosão do sagrado na poesia de João Cabral de Melo Neto. São Caetano do Sul: Ateliê Editorial, 1996; SILVA, Eli Brandão da. O nascimento de Jesus Severino no auto de natal pernambucano. São Bernardo do Campo. UMESP, Tese, 2001. Dos trabalhos aqui elencados, do ponto de vista de uma epistemologia para o chamado diálogo teologia e literatura, eu destacaria o de Eli Brandão da Silva.
} 


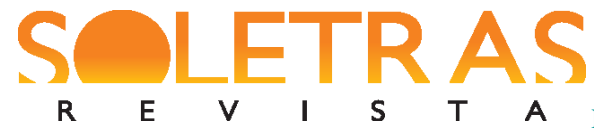

N.36 - 2018.2 - DOUGLAS RODRIGUES DA CONCEIÇÃO

substancialmente a teologia de seu rosto normativo, mas também como contraponto a uma tendência positivista proveniente das chamadas ciências positivas da religião, cuja consequência seria inevitavelmente um tipo uniformização das investigações científicas neste campo de estudos.

A teologia praticada nos programas de pós-graduação em Ciências da Religião tornara-se uma teologia mais livre e sensível às mais diferentes esferas da cultura. Talvez tenha sido esta a perspectiva admitida por Claude Geffré quando distinguiu o modelo dogmático do modelo hermenêutico de teologia (GEFFRÉ, 1989, p. 64-70). Tal liberdade indicava, portanto, que a teologia poderia ampliar mais ainda o seu olhar sobre a cultura secular e não somente olhar para as questões eclesiais e intrarreligiosas. Essa auscultada da cultura, sobretudo a das expressões artísticas, foi bastante devedora, pelo menos do Brasil, da recepção da chamada teologia da cultura do teólogo protestante Paul Tillich. Assim, a teologia se viu, em certo grau, como bem assinala Etienne Higuet, integrada ao rol das ciências hermenêuticas, isto é, "ciências que encontram a chave de compreensão dos objetos com os quais se ocupam num significado ou num sistema de significados" (HIGUET, 2006, p. 38), isto é, ciências que privilegiam a categoria do sentido.

O reconhecimento de que para certos domínios do fazer científico a significação desempenha um papel fundamental nos ajuda a compreender a presença que a literatura de escritores e poetas passou a ter no ambiente das Ciências da Religião. Entre as múltiplas formas de cotejamento da literatura nos estudos de religião, duas em particular parecem-me bem nítidas. a) a primeira se configuraria a partir do reconhecimento do potencial teológico da literatura, o que significa dizer que os temas da religião (o material da fé) deveriam também ser compreendidos enquanto matéria prima da estética literária, todavia passíveis a uma interpretação teológica ${ }^{3}$; b) a segunda, dar-se-ia a partir do reconhecimento de uma dimensão crítica estético-literária da literatura em relação à religião. Isto é: a literatura, através de suas formas de dicção, poderia ser compreendida como uma expressão das artes que convoca crítica e artisticamente a religião para os seus próprios domínios. Nesta

\footnotetext{
${ }^{3}$ Marie-Dominique Chenu escreveu um importante artigo acerca da reflexão teológica feita a partir da literatura. Cf. CHENU, M.-D. La littérature comme lieu de la théologie. Revue de sciences philosophiques et théologiques, v. 53, n. 1, 1969, pp. 70-80. Na mesma linha de Chenu, Jean-Pierre Jossua formulara a seguinte questão em sua célebre obra intitulada Pour une histoire littéraire de l'expérience religieuse. Jossua se perguntava o que então pode melhor dizer a literatura no lugar de uma teologia puramente conceitual acerca do mistério da fé e da existência cristã? Cf. JOSSUA, J.-P. Pour une histoire littéraire de l'expérience religieuse. Paris: Beuachesne, 1985. Vol 1.
} 


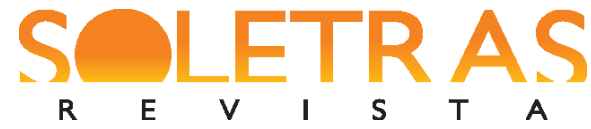

N.36 - 2018.2 - DOUGLAS RODRIGUES DA CONCEIÇÃO

perspectiva, a literatura conseguiria dizer que o domínio das artes, ao seu próprio modo e ao lado de outras vozes, também estabeleceu uma crítica à religião. ${ }^{4}$ Adiante evocaremos esta segunda perspectiva à luz da literatura brasileira.

\section{Crítica estético-literária nas letras brasileiras: dois casos “contemporâneos”}

Considerando muito parcialmente o panorama histórico da literatura brasileira, os textos de alguns poetas e prosadores parecem tornar a questão mais complexa, porque deles emanam elementos que claramente permitem uma reflexão a partir das duas perspectivas anteriormente aludidas. Ou seja: a partir de seus elementos composicionais e de modo nitidamente ostensivo, permitem não só uma reflexão teológica, isto é, uma espécie de teologia da literatura, mas também a percepção da arquitetura de uma crítica estético-literária em direção à religião. Na aurora da formação da literatura brasileira teríamos, assim penso, um caso bem emblemático. Trata-se do legado de Gregório de Matos. ${ }^{5}$ Embora não posta em questão por Antônio Cândido em sua célebre obra Formação da Literatura Brasileira: momentos decisivos, a literatura do poeta baiano representaria bem essa dupla dimensionalidade em relação à religião. Essa desatenção à literatura colonial brasileira por parte de Cândido - vale mencionar - foi brilhantemente criticada por Haroldo de Campos, na obra $O$ Sequestro do Barroco.

Em Gregório de Matos é possível enxergar, então, que não somente uma elaboração teológica, como certa cristologia, se apresentava em perspectiva (muitos sonetos de Gregório de Matos revelam esse traço), sobretudo, nos "poemas devotos", assim chamados por José Guilherme Merquior (2011, p. 59), mas também uma importante veia estético-crítica da literatura brasileira em relação à religião, o que o faz de algum modo um escritor moderno, provavelmente o primeiro das letras no Brasil. Se a crítica à religião for de fato uma das principais características da chamada modernidade, a literatura brasileira, tendo Gregório de Matos como ponto de inflexão, já nasceu moderna. Os dois poemas abaixo podem nos ajudar

\footnotetext{
${ }^{4}$ Karl-Josef Kuschel, em Os escritores e as escrituras, ao estudar a literatura de expressão alemã do século XX, chamou de tensa a relação estabelecida entre religião e literatura configurada a partir de uma crítica estéticoliterária à religião e também por uma crítica religiosa à estética literária. Cf. KUSCHEL, K.-J. Os escritores e as escrituras. São Paulo: Loyola, 1999.

${ }^{5}$ Eu sei que soará como uma heresia o uso do termo contemporâneo em referência a Gregório de Matos, mas a sua poesia (ou ao menos parte considerável dela) não poderia ser simples e indiscriminadamente encarcerada dentro uma mentalidade colonial apenas por razões cronológicas e históricas.
} 


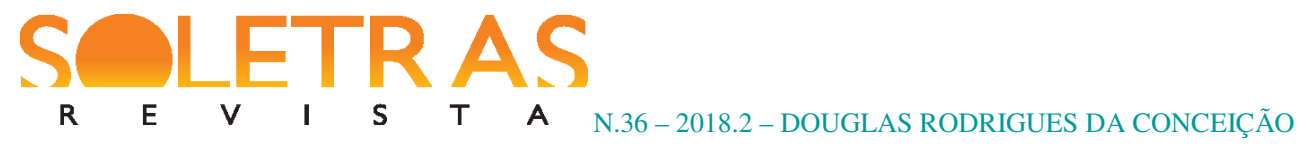

a perceber essa dimensão pendular da literatura de Gregório de Matos, que oscila entre uma teologia poética e uma crítica da religião. Isto é: acima de suas "fugas de idealidade, palpita o coração fauno impiedoso [...]" (Cf. SPINA, 1968, p. 245):

\section{A CHRISTO S. N. CRUCIFICADO ESTANDO O POETA NA ÚLTIMA HORA DE SUA VIDA}

Meu Deus, que estais pendente em um madeiro,

Em cuja lei protesto de viver,

Em cuja santa lei hei de morrer

Animoso, constante, firme, e inteiro.

Neste lance, por ser o derradeiro,

Pois vejo a minha vida anoitecer,

É, meu Jesus, a hora de ser ver

A brandura de um Pai manso Cordeiro.

Mui grande é vosso amor, e meu delito,

Porém pode ter fim todo pecar,

E não o vosso amor, que é infinito.

Esta razão me obriga a confiar,

Que por mais que pequei, neste conflito

Espero em vosso amor de me salvar.

(GREGÓRIO DE MATOS, 1992, p. 69)

\section{AO MESMO [padre] COM PRESUNÇÕES DE SABIO, E INGENHOSO}

Este Padre Frisão, este sandeu

Tudo o demo lhe deu, e lhe outorgou,

Não sabe musa, musae, que estudou,

Mas sabe as ciências, que nunca aprendeu.

Entre catervas de asnos se meteu,

E entre corjas de bestas se aclamou,

Naquela Salamanca o doutorou,

E nesta sala cega floresceu.

Que é um grande alquimista, isso não nego,

Que alquimistas do esterco tiram ouro,

Se cremos seus apógrafos conselhos.

E o Frisão as Irmãs pondo ao pespego,

Era força tirar grande tesouro,

Pois soube em ouro converter pentelhos.

(GREGÓRIO DE MATOS, 1992, p. 229)

Dito assim, vemos nascer em Gregório de Matos possivelmente a verve crítica mais ancestral na literatura brasileira em relação à religião e que foi conservada por escritores 


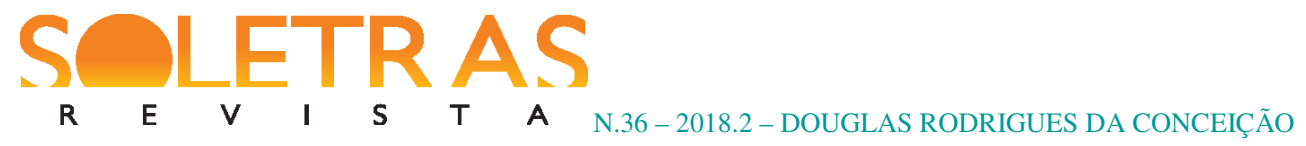

posteriores. A veia satírica e burlesca de sua poesia, além das mazelas da colônia, teve também a religião um dos alvos preferidos. Questões como o desprezo pelo clero e a denúncia de sua esterilidade presentes já estavam nos poemas daquele que foi chamado por Jorge de Amado de "o pai da nossa literatura" ou "Boca do inferno", tal como ficou popularmente conhecido. Gregório de Matos, afirma Segismundo Spina (1968, p. 246), fez da sátira o seu breviário. João Carlos Teixeira Gomes (1985) sintetiza bem o que representa o legado poético gregoriano:

Tendo sido um moralista às avessas, que só na poesia - e em mais nenhum outro gênero - encontraria a expressão adequada para liberar as conflagrações do seu tempo, Gregório de Matos, em plano tão oposto ao do obstinado missionário jesuíta - que pregou o Evangelho nas selvas, foi grande sobretudo quando resolveu escrever no Brasil uma espécie de Evangelho poético (e urbano) da zombaria, trocando as convenções da literatura gongorizante e culteranista pela imersão plena e total na vida e no seu momento histórico. Entre o céu, glorificado pelo ascetismo barroco, e a terra, cheia dos apelos do sensualismo dos trópicos, fez a opção sem remorsos da terra, que causticou com a sua musa impiedosa, tocado pela ideologia do riso (GOMES, 1985, p. 370).

Procurando entender essa tarefa de inquirição do seu próprio tempo, que é assumida pela literatura (seja prosa ou poesia) e que dilui as fronteiras entre o que seria o propriamente literário (quase limitado ao estritamente estético) e o propriamente crítico, enquanto tarefa mesma do discurso crítico, voz quase sempre propagada debaixo da chancela da filosofia, Maria Helena Varela chamou esse fenômeno de heterologos em língua portuguesa, que por sua vez não pode ser confundido com o mero exercício de criação de metadiscursos filosóficos tecidos pelos fios do texto literário. Sua forma plástica é o que ela chama de heterotexto polifônico, caracterizado por uma leve e sofisticada lógica e uma forte veia metafórica (VARELA, 1996, p. 29). O heterotexto não é um recipiente ou o reflexo do pensamento sistemático. Sob a máscara do belo, do criativo, ele destila um logos mais poético e menos no ético. É nessa linha estético-crítica, e em consonância direta com a poesia setecentista de Gregório de Matos, que a poesia de Luís Augusto Cassas ocupa um lugar singular na literatura brasileira contemporânea, muito embora não tenha ainda a atenção merecida. Essa dimensão particular da poesia de Cassas, de alguma forma, o faz um dos herdeiros do poeta barroco Gregório de Matos. 


\section{A poesia de Luís Augusto Cassas: o heterologos em atividade}

Duas de suas obras se destacam por convocar criticamente a religião: O Shopping de Deus \& a alma do negócio (1998) e Deus Mix: salmos energéticos de açaí c/ guaraná e cassis (2001). Cassas, que nasceu no Maranhão, em 1953, despontou na literatura nacional com a publicação da obra República dos becos, em 1981.

$\mathrm{Na}$ ausculta da contemporaneidade, o heterologos de Cassas, entre outros aspectos, faz da religião e da civilização do culto ao consumo matérias primas de sua poesia. Na obra $O$ Shopping de Deus \& a alma do negócio, Cassas procura mostrar a forma esquizo sob a qual o ser humano contemporâneo transparece. Para o humano de Cassas, servir a dois senhores, quais sejam, à religião e ao capitalismo, fórmula que rejeita o texto do Evangelho de Mateus 6:24, não implica a emergência de um conflito. O mix religião-homem-mundo lançado no liquidificador da sua poesia é uma espécie de mix quase sem sentido quanto um mix de açaí c/ guaraná e cassis. Ao fundir religião e cultura do consumo, numa verdadeira ode ao material, Cassas revela uma espécie de hipertranscendentalização no contemporâneo. O instrumento do heterologos de Cassas, pelo menos o mais evidente, é a paródia satírica (cf. GENETTE, 1982, p. 22).

Em Deus Mix, ao nomear cada um dos poemas de Salmo, fórmula na qual sempre agrega um adjetivo ou locução da mesma natureza, Cassas convoca explicitamente a bíblia. No poema Salmo do Verdadeiro Mandamento, como veremos, Cassas une a prescritividade dos mandamentos divinos ${ }^{6}$ ao apego às coisas, ou seja, ao culto aos bens rituais da religião do consumo. A ênfase dada por Jesus ao amor a Deus e ao próximo, nos Evangelhos, é deslocada para as coisas do mundo. Mas essa é também a tarefa do poeta: "ser tríblico" e não bíblico como foi o seu mais longínquo ancestral: o salmista. O poeta deve cantar não só Deus e o homem, mas também o mundo. Na abertura de Deus Mix, Davi, a quem a tradição bíblica tributa a autoria dos Salmos, diz ao próprio Cassas:

- Luís! Luís! Não te empacientes. Sou o mais antigo ancestral de teus pais. $[\ldots]$

\footnotetext{
${ }^{6}$ Por exemplo, no evangelho de Lucas, 10:27, o texto diz o seguinte: '[...] Amarás o Senhor, teu Deus, de todo o teu coração, de toda a tua alma, de toda as tuas forças e de todo o teu entendimento e ao próximo [amarás] como a ti mesmo'. Cf. BÍBLIA. Novo Testamento. Tradução de Frederico Lourenço. São Paulo: Cia. das Letras, 2017.
} 


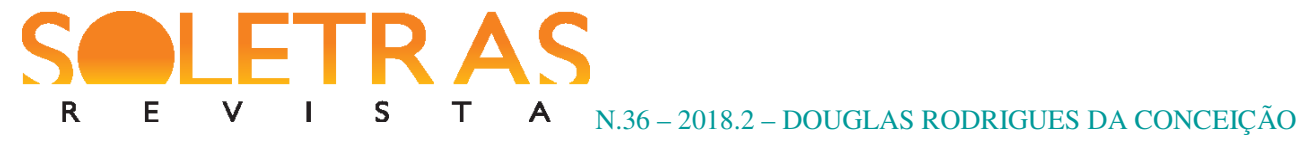

- Sou Davi, pai de Salomão, o que escreveu Os salmos e desde aquela época não tenho paz. Aplaca o meu espírito e a sabedoria dará notícias de ti nos telejornais.

- Fui bíblico. Celebrei Deus e o Homem em belos cantos devocionais. Mas esqueci-me de celebrar o Mundo. Redime as minhas noites de alcatraz. Canta Deus, o Homem e o Mundo. Sê tríblico e tua voz será ouvida no Monte Sinai. Deus compensará em dobro os teus direitos autorais. (CASSAS, 2012b, p. 69).

No poema Declaração de princípios, poema que abre a obra O Shopping de Deus, Cassas deslinda um dos fios de sua poesia: essa profusão entre o celeste e o terrestre:

\title{
DECLARAÇÃO DE PRINCÍPIOS
}

\author{
Vim do ventre do nada \\ pra dar voz ao todo: \\ encher o vazio \\ esvaziar o cheio \\ ligar o céu à terra \\ e unir a sabedoria de Deus \\ à sabedoria do Mundo
}

Meu nome não é Raimundo (CASSAS, 2012a, p. 513).

Nesse movimento arquitextual (penso mais explicitamente em Deus Mix), no sentido que lhe imprime Gérard Genette (1982), o poeta maranhense reavia o popularesco em seus poemas, que por seu turno era também um traço característico desse tipo de poesia proveniente do oriente-próximo antigo, de onde deriva a poesia dos Salmos, como bem sublinha Robert Alter (p. 300). ${ }^{7}$ Isto é: a poesia de Cassas trata da vida aí. Este é o mundo celebrado pelo poeta. A forma esquizo do ser humano na contemporaneidade - e a poesia de Cassas permitiria assim dizer -, sublinha a transformação das coisas em objetos de culto, a transformação do consumo em prática ritual e a transformação do combustível desse culto, o dinheiro, em um Deus, em coisa última. Os dois poemas a seguir sintetizam essa imagem do contemporâneo poeticamente fabricada pelo heterologos de Cassas:

\section{SALMO DO VERDADEIRO MANDAMENTO}

amar as coisas

acima de todas as coisas

\footnotetext{
${ }^{7}$ Robert Alter; Frank Kermode, Encyclopédie littéraire de la Bible, p. 300. 
desejar as coisas

mais que qualquer coisa aspirar às coisas antes de outra coisa em nome da salvação não pronunciar o santo nome em vão

(CASSAS, 2012b, p. 71-72)

\author{
ALMA DO NEGÓCIO \\ o dinheiro é um deu\$ terrível \\ que go $\$$ ta de $\$$ er adorado face a face \\ e paga à vi\$ta o\$ \$eu\$ milagre\$ \\ condecorando os vivo $\$$ com moeda $\$$ na língua \\ pra ab\$olvê-lo\$ da ferrugem do \$ol do\$ mi\$erávei\$ \\ quem penetra na arca de $\$$ \$e deu $\$$ \\ meditando \$obre \$ua\$ efígie\$ e cifrõe\$ \\ de $\$$ cobre que a vida é moeda barata \\ e oferta o \$acrifício da alma fal\$ificada \\ pra rena $\$ c e ̂-l a ~ b a n h a d a$ no ouro do $\$$ bandido\$ \\ lutar contra esse deu\$ é ab\$urdo \\ renegá-lo ou dar-lhe a $\$$ co\$ta $\$$ : anátema \\ ma interná-lo num a\$ilo de louco\$ \\ é re $\$$ \$u $\$$ itar do lucro a marca da criança \\ que ofertará flore $\$$ ao\$ fanta $\$$ ma $\$$ da inocência \\ ele é a ovelha que foi perdida e reencontrada \\ good i\$ money god i\$ money \\ a ovelha que extraviou a todo $\$$ e foi extraviada \\ a ovelha que por todo\$ foi penitenciada \\ e agora clama e chama por todo $\$$ na estrada \\ (CASSAS, 2012a, p. 543-544)
}

Substituindo o "S" pelo cifrão, Cassas habilita sobre o poema uma região semiótica de ordem visual. Símbolo inconteste do dinheiro, cuja religião que lhe rende um altar não é outra senão a do consumo e a do mercado, o cifrão torna-se a principal insígnia desta religião. ${ }^{8}$ Os dois primeiros versos "o dinheiro é um deu\$ terrível" e "que go\$ta de \$er adorado face a face" vincula a divindade da religião do consumo à imanência, ao terreno. O poder desta divindade não é invisível é táctil, é "pago à vi\$ta". O poema de Cassas diviniza o imanente (o

\footnotetext{
${ }^{8}$ No poema "Ladainha do cifrão", o elemento semiótico de natureza visual também é utilizado. Cf. CASSAS, 2012a, pp. 554-555.
} 


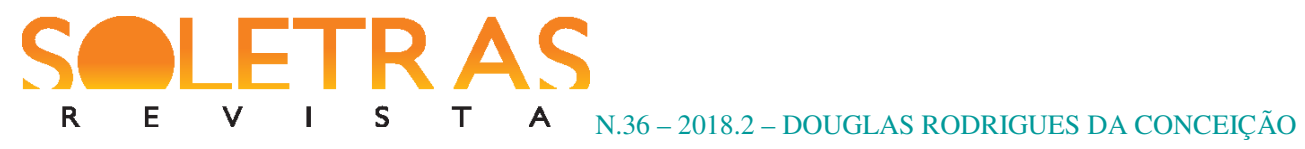

material) ao tempo em que reifica o transcendente. O dinheiro é um Deus que não se esforça para ser idolatrado. Aliás, "god i\$ Money".

No poema proclamação do feminino, a referência explícita ao evangelho de João e ao livro de Êxodo, formas palimpsésticas da bíblica tão caras à estética de Cassas, reforça essa identidade - diria ontológica - entre Deus e o dinheiro.

\title{
PROCLAMAÇÃO DO FEMININO
}

eu verba sou

antes do verbo

(CASSAS,2012a, p. 557)

A hipertranscendentalização exposta pela poesia de Cassas revela paradoxalmente, a um só tempo, a clausura do humano na radical imanência do seu existir e o seu incontido desejo em consumir. Vê-se aí uma espécie de paródia do cogito ergo sum (penso logo, existo). No caso da poesia de Cassas teríamos: consumo, logo existo. O homo religiosus confunde-se então com o homo consumens. Encarcerado numa atmosfera em que a religião do consumo é a totalidade, isto é, não cessa nunca, e suas práticas rituais só se intensificam, não terminam, o humano de Cassas se vê inteiramente enfeitiçado pelos ícones do mercado, cuja forma material é o shopping, templo mor da religião do dinheiro. No poema Salmo Capital, de Deus mix, Cassas parodia de maneira muito sutil a expressão latina Extra Ecclesiam nulla salus. Diz o poema :

\author{
SALMO CAPITAL \\ nada existe \\ fora do mercado \\ tudo é varejo \\ e atacado
} (CASSAS, 2012b, p. 90)

Extra Ecclesiam nulla salus quer dizer "fora da Igreja não há salvação". Os dois primeiros versos, "nada existe" e "fora do mercado", respectivamente, evocam certa analogia com o sacramento da comunhão oriundo da religião católica (universal). Os sacramentos para o catolicismo é o que propicia ao católico o compartilhamento da salvação proveniente de Deus. A religião do dinheiro, a que Cassas tece poeticamente, também é universal, mas o seu sacramento é único: não a comunhão, mas a consumação. Ela (a religião do dinheiro) é 


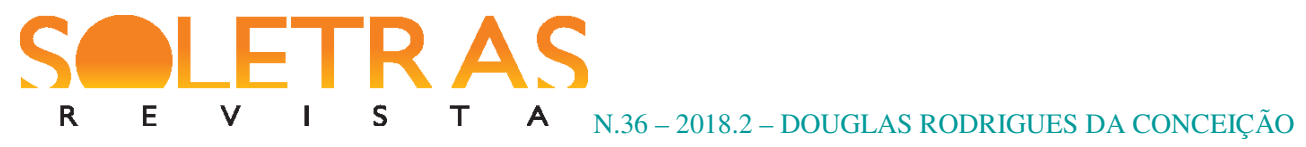

circular, nela não há salvação e o culto cujo rito central é o consumo não cessa jamais. A salvação, o fim da odisseia humana para a tradição cristã, é substituída pela ininterrupta idolatria/adoração aos bens ritualísticos do consumo. O "telos" é circular e não uma linear. Essa atmosfera inebriante do culto, na religião do dinheiro (Deus), é criativamente apresentada no poema "Invocação de Jack Daniels no reino do franchising":

\title{
INVOCAÇÃO DE JACK DANIELS NO REINO DO FRANCHISING
}

\author{
Pizza Hut \\ engordai o Senhor \\ Vinícola Aurora \\ embriagai o Senhor \\ Água de Cheiro \\ perfumai o Senhor \\ Mr. Cat \\ calçai o Senhor \\ Holliday In \\ hospedai o Senhor \\ Sorvetes Babuska \\ deliciai o Senhor \\ Móveis Hobjeto \\ descansai o Senhor \\ Dr. Sholl \\ desencravai o Senhor \\ Golden Cross \\ recuperai o Senhor \\ Transbrasil \\ viajai no Senhor \\ Giorgio Armani \\ vesti o Senhor \\ NET e INTERNET \\ celebrai o Senhor \\ porque toma emulsão de scott \\ o Senhor é forte \\ porque usa salsaparrilha \\ o Senhor produz maravilhas \\ porque usa produtos kibon \\ o Senhor é bom \\ porque toma todo dia toddy \\ com Ele ninguém pode \\ (CASSAS, 2012a, p. 570)
}

O poema satiriza grifes e marcas que com seu cintilante e sagrado poder de sedução dá aos devotos da religião do consumo a comunhão com o mercado e o equivalente da salvação no mundo, ou seja, a sensação de bem estar. Sublinhando a reverência prestada pelo homo 


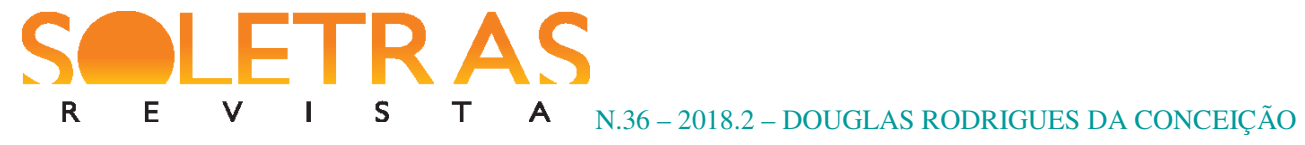

consumens em sua devota e incontida necessidade de consumi-las, Cassas faz o poema entoar uma espécie de oração que se confunde com um jingle publicitário. ${ }^{9}$

É dessa forma que a poesia de Cassas se exprime: um tanto satírica e um tanto barroca. ${ }^{10}$ No heterologos de Cassas, ao menos nos poemas convocados, o sagrado não se aparta da materialidade do mundo. Ao contrário, imanentiza-se a ele. O sagrado dilui-se à tórrida imanência. E o poeta confessa:

\title{
ENTRE DOIS AMORES (2)
}

\author{
1 \\ Tenho dois amores: \\ Deus e o mundo \\ Um é amor cigano \\ Outro é amor profano \\ Um me toca a fundo \\ Outro me toca o pano \\ 2 \\ Deus e o Mundo \\ não é nenhum carnaval \\ Deus e Mundo \\ é o batismo do bem sobre o mal \\ Deus e o Mundo \\ é a fusão do ideal e do real \\ 3 \\ Deus e o Mundo \\ não é nenhuma ilusão \\ Deus e o Mundo \\ é a união da fé e da razão \\ Deus e o Mundo \\ é amar o céu de pé no chão \\ 4 \\ Deus e o Mundo \\ é a ponte sobre o abismo
}

\footnotetext{
${ }^{9}$ Cf. COELHO, Marcelo. Fortuna crítica. In: CASSAS, Luís Augusto. A poesia sou eu, poesia reunida. Rio de Janeiro: Imago, 2012a, p. 678.

${ }^{10}$ Cf. NEJAR, Carlos. Fortuna crítica. CASSAS, Luís Augusto. A poesia sou eu, poesia reunida. Rio de Janeiro: Imago, 2012b, p. 693.
} 


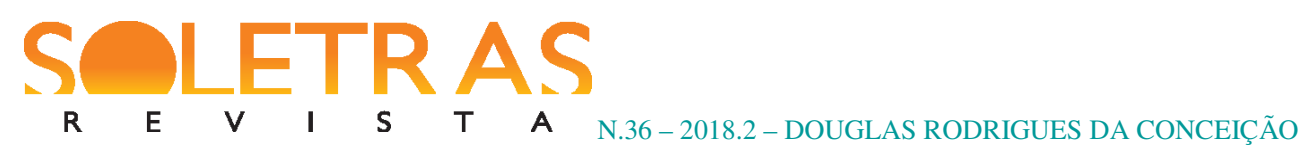

\author{
Deus e o Mundo \\ é o verdadeiro paraíso \\ Deus e o mundo \\ é o nosso maior surrealismo \\ (CASSAS, 2012a, p. 515-516)
}

\title{
Considerações finais
}

No Brasil, o rosto primordial da atenção à literatura no campo das Ciências da Religião procurou estabelecer uma espécie de teologia da literatura. Teólogos e teólogas, sobretudo, viam-se cientificamente mais transgressores e na vanguarda dos estudos de religião ao procurar na literatura um lugar para o seu trabalho. Certo é que um olhar mais proficiente acerca de uma crítica feita pela literatura brasileira em relação à religião ainda está por ser realizada.

Não saio em defesa nem de uma teologia da literatura (JOSSUA, 2000) nem de uma crítica à religião feita pelas expressões literárias. Sem moderação, quem toma a literatura como lugar teológico pode correr o risco de diminuir as expressões literárias a um campo de exercícios de teologia; noutra direção, quem se aproxima da literatura procurando fazer dela apenas mais um eco da crítica moderna à religião certamente a empobrecerá. Seria no mínimo razoável admitir a existência, em certa medida, de uma relação de cumplicidade entre a religião e a literatura. $\mathrm{O}$ alcance da religião através dela, o que por si só revela um alto grau de interconexão entre essas duas faces da cultura humana, não poder ser de modo algum totalmente gratuito. Se Roland Barthes (2007) tem mesmo razão ao afirmar que escritores (e também os poetas eu diria por minha própria conta) preocupam-se antes tudo com a sua linguagem, poderíamos dizer então que a literatura faz da religião um importante grafema, ou seja, uma unidade de sentido ou matéria prima ou elemento estético que torna a própria linguagem (ou seja, a linguagem da literatura, a linguagem literária) mais nítida, mais legível e artisticamente mais rica. Por outro lado, transparecendo no tecido da literatura, a religião se conserva ao fazer das expressões literárias sua memória. Considerando factível o primeiro horizonte, já não seria possível afirmar, por exemplo, que Cassas põe à frente da sua poesia a lucidez da crítica, da crítica solar do Aufklärung, do logos que repreende e acusa o homem contemporâneo de viver enclausurado numa forma outra de delírio religioso. Talvez Cassas 


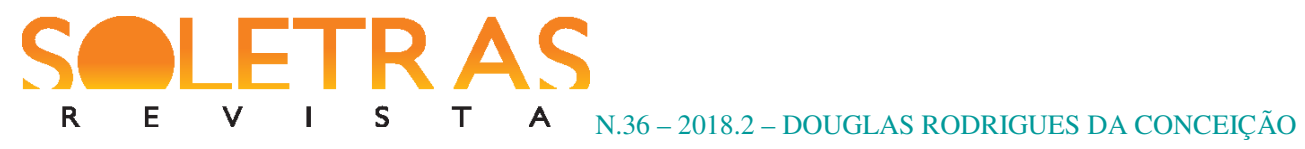

não tenha chegado à poesia através de uma crítica à cena contemporânea, mas ao contrário. Escandindo versos como quem afia uma lança, Cassas talvez tenha chegado a uma forma de crítica pelo viés da poesia. Assim, o poético em Cassas seria o ato primeiro.

Saudando o poeta maranhense, Carlos Drummond de Andrade escreveu: "forte e bela poesia, atenta à vida humana e às questões de nosso tempo" (2012a, p. 646). Drummond se referia ao primeiro livro de Cassas, mas tal observação pode ser distendida, e por que não?, às obras de 1998 e 2001. Zeca Baleiro (2012b, p. 604), outro poeta maranhense, saudou o criado de Deus mix dizendo: "Saravá, poeta! Que Minerva te abençoe! Digo Minerva a divindade, não o sabão em pó.” Savará, Cassas! Eu vos saúdo também.

\section{Referências}

ALTER, Robert. Psaumes. In: ALTER, Robert; KERMODE, Frank. Encyclopédie littéraire de la Bible. Paris: Bayard, 2003.

BALEIRO, Zeca. Fortuna crítica. In: CASSAS, Luís Augusto. A poesia sou eu, poesia reunida. Rio de Janeiro: Imago, 2012b. Vol. 2.

BARTHES, Roland. Crítica e verdade. 3. ed. São Paulo: Perspectiva, 2007.

BÍBLIA. Novo Testamento. Trad. Frederico Lourenço. São Paulo: Companhia. das Letras, 2017.

DRUMMOND DE ANDRADE, Carlos. Fortuna crítica. In: CASSAS, Luís Augusto. A poesia sou eu, poesia reunida. Rio de Janeiro: Imago, 2012a, v. 1.

CANDIDO, Antonio. Formação da literatura brasileira. Momentos decisivos (1750-1880). 13. ed. Rio de Janeiro: Ouro sobre Azul, 2012.

CASSAS, Luís Augusto. A poesia sou eu, poesia reunida. Rio de Janeiro: Imago, 2012a, v.1. .A poesia sou eu, poesia reunida. Rio de Janeiro: Imago, 2012b, v.2.

CHENU, M.-D. La littérature comme lieu de la théologie. Revue de Sciences philosophiques et théologiques, v. 53, n. 1, 1969.

COELHO, Marcelo. Fortuna crítica. In: CASSAS, Luís Augusto. A poesia sou eu, poesia reunida. Rio de Janeiro: Imago, 2012a.

GEFFRÉ, Claude. Como fazer teologia hoje. Hermenêutica teológica. São Paulo: Paulinas, 1989. 


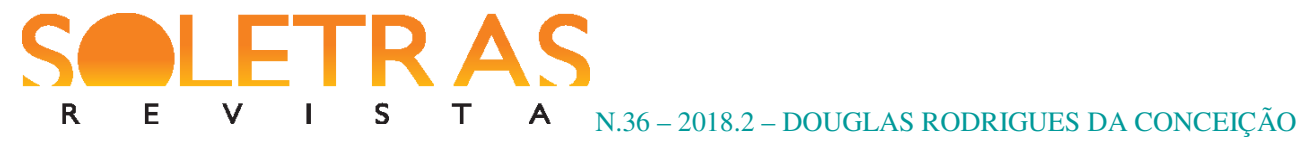

GREGÓRIO DE MATOS.Obra poética. 3.ed. Edição de James Amado; preparação e notas de Emanuel de Araújo. Rio de Janeiro: Record, 1992, v. 1.

Obra poética. 2.ed. Edição de James Amado; preparação e notas de Emanuel de Araújo. Rio de Janeiro: Record, 1990, v. 2.

GENETTE, Gérard. Palimpsestes. Paris: Seuil, 1982.

GOMES, João Carlos Teixeira. Gregório de Matos, o boca de brasa (Um estudo de plágio e criação intertextual). Petrópolis, RJ: Vozes, 1985.

HIGUET, Etienne Alfred. A teologia em programas de Ciências da Religião. Revista Eletrônica Correlatio, São Paulo, n. 9, 2006, p. 37-50.

JOSSUA, J. -P. Pour une histoire littéraire de l'expérience religieuse. Paris: Beuachesne, 1985.

La littérature et l'inquiétude de l'absolu. Paris: Beauchesne, 2000.

KUSCHEL, K. -J. Os escritores e as escrituras. São Paulo: Loyola, 1999.

MERQUIOR, José Guilherme. De Anchieta a Euclides. Breve história da literatura brasileira. 4. ed. São Paulo: É Realizações Editora, 2011.

SPINA, Segismundo. Gregório de Matos. In: COUTINHO, Afrânio (Dir.). A literatura no Brasil. 2. ed. Rio de Janeiro: Editorial Sul Americana S.A., 1968.

MAGALHÃES, Antonio. Deus no espelho das palavras: teologia e literatura em diálogo. São Paulo: Paulinas, 2001.

MANZATTO, Antonio. Teologia e literatura: reflexão teológica a partir da antropologia contida nos romances de Jorge Amado. São Paulo: Loyola, 1994.

NEJAR, Carlos. Fortuna crítica. CASSAS, Luís Augusto. A poesia sou eu, poesia reunida. Rio de Janeiro: Imago, 2012b.

TENÓRIO, Waldecy. A bailadora andaluza: a explosão do sagrado na poesia de João Cabral de Melo Neto. São Caetano do Sul: Ateliê Editorial, 1996.

Escritores, gatos e teologia. Cotia, SP: Ateliê Editorial, 2014.

SILVA, Eli Brandão da. O nascimento de Jesus Severino no auto de natal pernambucano. São Bernardo do Campo. UMESP, Tese, 2001.

VARELA, Maria Helena. O heterologos em língua portuguesa. Rio de Janeiro, 1996. 


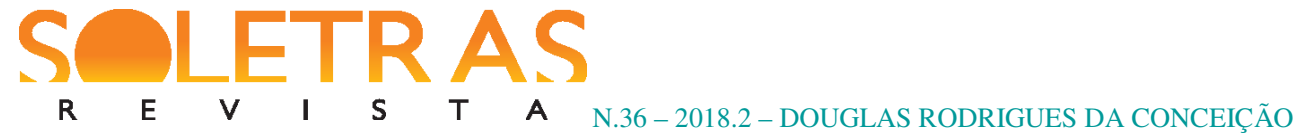

\section{Religion as a raw material for poetry}

Abstract: The present article aims at analyzing the poetry of Luís Augusto Cassas through the relationship between religion and literature that was established in the Religious Studies research field. However, in order to do that, it seems essential to briefly visit the poetry of Gregório de Matos as a means to not only propose a critique of religion through Cassas' poetry but also a reflection on religion itself as the primal source of inspiration in literature.

Keywords: Religion. Poetry. Critique. Luís Augusto Cassas.

Enviado em: 28 de abril de 2018.

Aceito em: 23 de junho de 2018. 